\title{
USING STORIES TO ASSIST STORYTELLING IN A PASTORAL SETTING: FOUR FEMALE pastors in dialogue With Mary Magdalene
}

\author{
Authors: \\ Sanrie de Beer ${ }^{1,2}$ \\ Julian Müller ${ }^{1}$

\section{Affiliations:} \\ ${ }^{1}$ Department of Practical \\ Theology, University of \\ Pretoria, South Africa \\ 2Student Chaplain of the \\ Netherdutch Reformed \\ Congregation Philadelphia, \\ University of Pretoria, \\ South Africa

\section{Correspondence to:} \\ Sanrie De Beer \\ e-mail: \\ sanrie@worldonline.co.za
}

Keywords:

Mary Magdalene; female pastors; pastoral storytelling; Gospel of Mary; textual analysis

\section{Postal address:}

512 Powell St, Pretoria

Gardens, 0082, South Africa

\section{Dates:}

Received: 21 Feb. 2008

Accepted: 19 Mar. 2009

Published: 23 Apr. 2009

How to cite this article: de Beer, S. \& Müller, J., 2009, 'Using stories to assist storytelling in a pastoral setting: Four female pastors in dialogue with Mary Magdalene', HTS Teologiese Studies/Theological Studies 65(1), Art. \#149, 5 pages. DOI: $10.4102 /$ hts.v65i1.149

\section{This article is available} at: http://www.hts.org.za

\section{Note:}

This article is a reworked version of Dr Sanrie de Beer's thesis, submitted as part of the requirements for the degree MA in Practical Theology (2007) at the Faculty of Theology of the University of Pretoria, under the supervision of Prof. Dr J. Müller.

\section{(C) 2009. The Authors.} Licensee: OpenJournals Publishing. This work is licensed under the Creative Commons Attribution License.

\section{ABSTRACT}

Sometimes we need a source of encouragement for restoring our own lives, to help us re-create ourselves. Using text as narrative texts opens up a multitude of possibilities in the work with clients in therapy. The story of Mary Magdalene told in John 20:11-18 is considered to be a healing story. This article aims to retell the story of her encounter with the resurrected Jesus, using the Gospel of Mary as an enlightening intertext. Because the story of Mary Magdalene's encounter with Jesus is used as a healing story, the basic principles of transformative narrative theory are considered to be useful in the analysis of this text. Mary Magdalene's story is then discussed with three female pastors of the Netherdutch Reformed Church of Africa. The research opened up a discussion about spirituality. This article would be incomplete without reflecting on the spirituality stories of the group of co-researchers.

\section{INTRODUCTION}

Susan Albert comments as follows on the power of stories:

Our lives are made of stories: stories handed down from our parents, stories we have created out of our experience, stories about our loves, our words, our explorations, our joys, our disappointments, our learning - the soul's story. By creating stories, we create and re-create ourselves.

(Susan Albert 1996:ix)

Sometimes we need a source of encouragement for restoring our own lives, to help us re-create ourselves. Using text as narrative texts opens up a multitude of possibilities in the work with clients in therapy. Epston and White (1992:89-91) emphasise that when persons of all ages spontaneously report on the content of a favourite story, this story functions as a 'safe' vehicle for them to talk about their own lives, experiences and emotions that have been marginalised or shaped to fit transgenerational themes. Epston and White encourage therapists to use actual fictional texts in narrative therapy, as these texts are accessible to clients and allow them to look at their problems and circumstances in the safe context of reading and listening.

Epston and White (1992:91) urge the beginner therapist, in learning about narrative therapy, to consider the metaphor of narrative in a literal way by externalising the experience completely before deconstructing and integrating reauthored or preferred stories. This 'literal metaphor' is a real text, novels and/or stories that have been labelled 'good' and can therefore be integrated into a person's experience as 'good'. It is thus a good story or a positive narrative. Epston and White (1992:12) suggest that the therapist identify and discuss the client's experience of a novel/story '....concentrating on the various levels at which the client felt engaged in or absorbed by the story, and how they identified with certain characters in the story'.

I consider the story of Mary Magdalene told in John 20:11-18 to be a healing story. My intention is to retell the story of her encounter with the resurrected Jesus, using the Gospel of Mary (see Robinson 1990:523-527) as an enlightening intertext. Mary Magdalene's story will also be discussed with three female pastors of the Netherdutch Reformed Church of Africa. My own personal involvement in this endeavour is confessed for I assume that storytelling is not merely a method for solving particular problems that crop up in our lives but also has an importance and integrity of its own, as a means to personal wholeness. In this sense, it is a spiritual activity, enabling us to become more of who we are, more authentic and more alive (Atkinson 1995:51).

This retelling of Mary Magdalene's story may possibly encourage us as readers/listeners to retell our own experiences. Our experiences as female pastors in the church and our interpretation of Mary's retold story will be listened to and reported and may possibly enable us to reauthor our own experiences in a mainly male-orientated church. Who knows what this journey together with other female pastors may lead to?

\section{TRANSFORMATIVE NARRATIVE THEORY}

\section{Introduction}

Because the story of Mary Magdalene's encounter with Jesus is assumed to be a healing story, the basic principles of transformative narrative theory are considered to be useful in the analysis of this text. Narrative theory is based on the idea that people's lives and relationships are shaped by the stories that people tell and engage in to give meaning to their experiences. We construct certain habits and relationships that constitute various ways of living and assist us to stay true to our internalised stories. The narrative therapist assists persons to resolve problems by enabling them to deconstruct the meaning of the reality of their lives and relationships and to show the difference between the reality and the internalised stories of the self. The narrative therapist encourages clients to reauthor their own lives according to alternative and preferred stories of self-identity and according to preferred ways of life (Epston \& White 1990:5-18). Transformative narrative therapy stresses the importance of reauthoring one's life story. As the term implies, it aims at nothing less than the transformation of the person and the social ecology. It does so through changing one's meaning constructs about the self and the world. 
Therefore it is also referred to as meaning-centred narrative therapy (Epston \& White 1990:3-57)

Here are some of the basic principles of transformative narrative therapy:

- It is dialectical and paradoxical. It embraces the paradox of evil and good coexisting and hope and despair living together. Furthermore, it believes that the synthesis of opposites gives rise to a new condition that is stronger than the initial positive. Thus, a person is encouraged to integrate her or his problem-saturated stories with alternative ones, resulting in a more encompassing and a compelling new narrative.

- It is symbolic. The transformation is more fundamental and far-reaching when it occurs at a symbolic level. Expressing our deepest longings, symbols are what dreams are made of. More importantly, symbols tap into our spiritual potential and reveal glimpses of sacred moments. Therefore, everyday trivia take on new meaning by symbolic transformation. Even negative events, whether early childhood abuse or adult traumatic experiences, can become symbolic of something spiritual, something positive.

- It is heroic. It does not seek easy victories, nor does it aim at superficial solutions. It demands taking a courageous stance in life; it requires an unwavering willingness to confront and slay one's dreaded dragon. The end result is that a victim's journey is transformed into a hero's adventure. The new story finally takes hold when it results in transforming the environment in which one moves and lives.

In order to listen to Mary Magdalene's voice as well as the voices of my co-researchers, a narrative approach is viewed as being useful.

\section{A narrative approach}

\section{The aim of a narrative approach}

The aim of a narrative approach is to enquire into the manner in which individuals give meaning to facts and actions in their world of experience (Ganzevoort 1989:10). The aim of research is to gain insight. It is not the content of a matter that is important but the manner in which persons handle it and give meaning to it. The narrative investigation does not aim to restate a present hypothesis but to bring alternative research stories to life. This method is qualitative in nature because its interest is not in numbers and quantifiable generally accepted evidence but in the search for experience and meaning (White 1998:219-228).

In narrative research actions and events are placed according to their contribution to the development of the research narrative. Narrative research emphasises the following key terms: human beings as active participants and focus on meaning, movement away from positivism where existing knowledge is viewed as the only legitimate understanding of reality, a change in the relation between researcher and the traditional 'subject' of research and the confession of the researcher's own subjectivity that influences research.

\section{Theoretical assumptions}

The following theoretical assumptions are seen as beacons for research:

- The client is the expert: Clients are viewed as experts of their own lives. (Freedman \& Combs 2002:24-26).

- Not knowing: The researcher tries to know more about the research narrative. Our efforts to understand are not limited to previous experiences of theoretical knowledge. The researcher is therefore forced to be aware of his/her own assumptions (Freedman \& Combs 1996:44-45).

- Externalisation: According to the narrative approach, the person is not the problem but the problem is the problem (White 1998:11-40). The person's problem is not situated within the person but is externalised by conversation and the use of metaphorical language.
- Unique outcomes and alternative stories: Unique outcomes focus on possibilities (White 1998:74). Unique outcomes are the seemingly unimportant, sometimes forgotten experiences opposing the dominant story of disappointment.

- Co-construction: The narrative conversation is an 'in-theretogether' experience. In conversation new meanings, new realities and new narratives are constructed (Freedman \& Combs 1996:87-93).

\section{MARY MAGDALENE'S ENCOUNTER WITH THE RISEN JESUS: FACT OR SYMBOL?}

Before analysing the story of Mary Magdalene as a healing story, one should be clear about the manner in which the text is read. Does this text reflect a historical incident or should it be interpreted as a symbol? To the degree that a story is coherent, each part is deemed to have meaning, not in an abstract philosophical sense or in an ethical one but a narrative meaning, meaning within the framework of the story as a whole. The ancient Greeks refer to this as mythos or myth (Kenyon \& Randall 1997:10). In this sense, myth and narrative are synonyms.

Joseph Campbell (1982:60) argues that a myth/narrative can be interpreted as prose (a historical occurrence) or poetry (symbolic). Myth read as poetry is not necessarily concerned with the factual, historical basis of an event but enquires into its symbolic meaning, its power to reshape and restory an individual's life. The story of Mary Magdalene's encounter with the resurrected Jesus is thereby read as poetry. The narrative is interpreted as a myth in the classic sense, not as something automatically unscientific or untrue but as a guiding plot by which the world is rendered coherent to us so that we can live with meaning and hope.

The Gnostic text the Gospel of Mary (150 CE) is mapped onto John's version of Mary's encounter with Jesus. John's (90 CE) connection with an early form of Gnosticism has been recognised by scholars such as Bultmann (1971). Therefore the connection between the narrative in John 20:11-18 and the Gospel of Mary is valid because it shows the development of narrative ideas within the same tradition. In a sense, the story of Mary's encounter with Jesus narrated in John 20:11-18 is continued in the Gospel of Mary.

\section{QUESTIONS POSED TO MARY MAGDALENE}

The basic principles of transformative narrative therapy make way for a logical analysis of the story of Mary's encounter with Jesus. In order to be respectful to Mary Magdalene's voice, I will give her the opportunity to answer my questions. I realise my questions may limit her in relating her story. My questions may even force her to relate a story typified as a 'thin description' (see Morgan 2000:12-14). Being aware of these limitations, I tried to listen to her voice and formulate questions presenting her with an opportunity to talk freely.

Three principles underlying transformative narrative theory give the substance of the questions posed to Mary Magdalene. These questions are the following:

- In what way does your story supply solutions to the integration of paradoxes?

- How does the story of your encounter with the risen Jesus give way to symbolic interpretation?

- In what way do you act as the heroine of your story?

\section{LISTENING TO MARY MAGDALENE'S STORY}

\section{My story's solution to the integration of} paradoxes

In verse 11 of John 20 you met me weeping bitterly while I stood 
beside Jesus' tomb. Why did I weep for the Jesus figure? Jesus gave me a voice in a patriarchal society; he gave me identity and a reason for living against all odds. In this sense, I represent all females in a patriarchal society, voiceless and without identity. My hope was built on Jesus and my hope died with him. Jesus represented hope for the change of order. He restored balance in an imbalanced society. The Gospel of Mary sheds light on the effect of my encounter with Jesus (Meyer 1985:554-570).

In this gospel (see Robinson 1990:523-527) I explain Christ's teachings to me communicated during our encounter. Christ told me that $\sin$ is not a problem of moral ignorance so much as a manifestation of the imbalance of the soul. Christ encourages us, his disciples, to spread his teachings and warns us against those who teach of spirituality as an external concept rather than an internal Gnostic experience. Jesus should therefore be internalised. Jesus taught me that the internalised Christ brings about balance in an imbalanced soul, an imbalance that results in sin (King 2003:49-58). The internalised Jesus is therefore presented as the balance between the paradox of evil and good, despair and hope. The synthesis of opposites gives rise to a new condition, that of spirituality, wholeness and integration within a person, which ultimately results in a balanced society.

My encounter with the risen Jesus narrated in John 20:14-17 (in the Gospel of Mary this encounter takes place by means of a vision) brought about a change within me in the sense that balance between hope and despair, good and evil on a personal level was restored. It also had an effect on societal level: It provided me with a voice. This means that the chauvinistic disciples no longer saw me as a powerless woman but as a person who deserved respect. I am described by Levi as 'the one most loved by Jesus' (King 2003:13-28). After my encounter with the risen Jesus, I lifted the hearts of the disciples who had become despondent about Christ's departure. My desperation narrated in John 20:11 made way for encouragement. I motivated the disciples as follows:

Do not weep and do not grieve nor be irresolute, for His grace will be entirely with you and will protect you. But rather let us praise His greatness, for He has prepared us and made us into men.

(King 2003:24)

\section{The resurrection story: A symbol of rebirth/ restoring}

John, narrating my story, painted a picture of me mourning for Jesus near his grave. He described me seeing a man I took to be the gardener. When he spoke my name, I recognised the presence of Jesus. He ordered me not to touch him. This is in contrast with John 21 stating that Jesus insisted on the disciples touching Him to prove that He was not 'a ghost'.

The Gnostic Christians rejected the literal view of the resurrection. They insisted that the resurrection was not a unique event in the past but symbolised how Christ's presence could be experienced in the present. It was not a factual seeing that mattered but spiritual vision (Pagels 1979:12-13). In the gospel attributed to me, I describe the resurrection appearances as visions received in dreams. This gospel also recalls a tradition of me being the first to see the risen Christ.

Whether the risen Jesus is perceived in a material or bodily matter or through a vision, to me it is a symbol of rebirth, a migration into newness for the person encountering the phenomenon (King 2003:69-82). The resurrection becomes a symbol of restoring. The resurrection of Jesus gave me the courage to face the disciples Andrew and Peter who questioned my credibility. I stood up to them; I, a mere woman who wasn't allowed to speak

1.This difference can possibly be explained by the fact that John 21 is universally recognised as having been a supplement to the original text of this gospel (Duling \& Perrin 1994:410). John therefore depends on a tradition identifying Mary Magdalene Perrin 1994:410). John therefore depends on a tradition identifying Mary Magdalene
as the first witness of the resurrection though emphasising the physical presence of Christ. in men's presence. The risen Jesus enabled me to fulfil myself by maximising my use of abilities, skills and potential, acting as the first witness to the risen Christ and proclaiming his message to the world. The disciples followed me in being a witness of Christ.

\section{Mary Magdalene's story: A story of heroism}

My encounter with Jesus, narrated in John 20:11-18, encouraged me to communicate my story to the disciples. The content of this telling is reflected in the Gospel of Mary. I, the victim of sorrow, became the first witness of the risen Jesus and the spokeswoman for Jesus' message to the disciples and ultimately to the world (Price 1990:54-76). The end result is that a victim's journey is transformed into a hero's adventure. This gospel narrates how I had to face Andrew and Peter's disrespect and ridicule on delivering the Saviour's message to them. Peter - for one questioned my credibility:

Peter answered and spoke concerning these same things. He questioned them about the Saviour: "Did He really speak with a woman without our knowledge (and) not openly? Are we to turn about and listen to her? Did He prefer her to us?" Then Mary wept and said to Peter: "My brother Peter, what do you think? Do you think that I thought this up myself in my heart, or that I am lying about the Saviour?" Levi answered and said to Peter: "Peter you have always been hot-tempered. Now I see you contending against the woman like the adversaries. But if the Saviour made her worthy, who are you indeed to reject her? Surely the Saviour knows her very well. That is why He loved her more than us. Rather let us be ashamed and put on the perfect Man, and separate, as He commanded us and preach the gospel, not laying down any other rule or law beyond what the Saviour said." And when they heard this, they began to go forth to proclaim and to preach.

(King 2003:25)

According to Pagels (1979:16) the narration of my story in the Gospel of Mary has important political implications: Peter and Andrew represent the leaders of the Early Church, whereas I represent a Gnostic viewpoint. I lacked the proper credentials for leadership, from the orthodox viewpoint: I am not one of the 'twelve' and I am female. But as I stood up to Peter, so the Gnostics, who took me as their prototype, challenged the authority of those priests and bishops who claim to be Peter's successors. I, a mere woman, therefore replace Peter, the rock of the Early Church, as the first witness of the resurrection of Jesus and thereby become the authoritative figure whereupon the authority of the Gnostic movement is based. In this sense, I was able to give life to something much bigger than myself (King 2003:83-85). I became the heroine of the Christian movement. In this manner the credibility of the Early Christian Church, pictured as an exclusive male movement, is challenged.

\section{REFLECTION: THE STORY OF MARY MAGDALENE AND THE STORY OF MY}

\section{LIFE}

I had the opportunity and privilege to listen to Mary Magdalene's story. Her story had a huge effect on me. Her story may be regarded as an endeavour to set out on a journey searching for the 'soul' (Kenyon \& Randall 1997:121). I interpret Mary's meeting with Jesus as a metaphor for this journey into the Self. On meeting Jesus, this desolate, hopeless woman becomes an integrated, hopeful person, the heroine of her story, able to confront her opponents, courageous and transformed.

By interpreting the resurrection of Jesus as a symbol of spiritual rebirth and presenting the internalised Jesus as furnishing the means through which one could bring about a balance between the paradox of evil and good, despair and hope, a new condition is realised. This new condition is that of spirituality, wholeness and integration, resulting in a changed society where there is respect for the value of persons.

In a patriarchal society, Jesus gives Mary a voice and transforms 
her into the pillar of the Christian movement. Mary's rebirth, the re-authoring of her life, therefore has an effect on her environment. She encourages the disciples to proclaim the message of Jesus' rebirth within a person.

Her story inspires me to take a courageous stance in life and gives me a willingness to confront and slay my own dreaded dragons. It brings about the hope that, like Mary's story, any person's story may be one of a victim's journey transformed into a hero's adventure. This transformation should also manifest itself in new directions, new goals and new patterns of living. A new story finally takes hold when it results in the transformation of the environment in which one lives. To me, Mary's story is a healing and liberating story.

\section{THE STORY OF OUR GROUP}

For the purpose of this research story, I contacted female pastors of the Netherdutch Reformed Church of Africa. Because I am a pastor in this church, the choice of limiting myself to my own denomination was simply a practical choice. Three pastors agreed to be involved in an experience with unknown results. Their consent paved the way for a dauntless but nevertheless terrifying journey together. I identify myself with the following statement made by Freedman and Combs concerning the idea of 'goal setting' in the narrative process:

The narrative metaphor biases us toward thinking about possibilities that unfold in a living story, rather than about goals, which are usually set in advance and pursued more-or-less singlemindedly. Instead of goals, we tend to speak of "projects" or "directions in life".

(Freedman \& Combs 2002:21)

My 'project' in research was to facilitate the opportunity for my co-researchers and me to reflect on our own stories as female pastors in the church and the story of Mary Magdalene as a possible healing or alternative story. The intriguing question was, How? According to Rubin and Rubin (1995:26-31), focus groups are the obvious choice regarding the following scenarios:

- To enquire into the ideas and feelings of people regarding certain themes

- To understand differences among groups

- To identify factors influencing opinions, motivations and behaviours

- To generate ideas

- To test ideas, material, plans or policies

- To generate information, thereby illuminating quantitative data already collected

- To enquire into the language and commentaries of the focus group.

My expectations of my co-researchers are included in the abovementioned list: to enquire into the ideas and feelings of people regarding a certain theme and to generate new ideas. In this way a 'rhythmic alternation between telling and witnessing which characterizes narrative work' (Freedman \& Combs 2002:22) is achieved.

Rubin and Rubin (1995:66) state three criteria to which the coresearchers should answer. I was led by these criteria:

- Co-researchers should have knowledge of the situation being discussed

- They should be willing to talk

- They should represent different opinions.

I randomly called female pastors, explaining the aim of my study, and three agreed to be part of it. The conversation by telephone involved the following elements:

- The nature of the study was explained.

- The importance of involving co-researchers in the process was communicated. I explained why I called the specific person and that an agreement was involved in the process.

- The practical arrangements (the time, date and place of our meetings) and the promise to e-mail a consent form explaining the aim of the study were communicated and the modus operandi and my consent to maintain confidentiality were explained.

Our group met several times. We agreed to share our stories of our experiences as female pastors in the church. After naming our stories and sharing with one another, we were ready for Mary Magdalene's story. I e-mailed my conversation with Mary Magdalene to my participants in research. We met to talk with her and to discuss what we had gained from her story. My research forced me to gain a broader perspective of my own struggles and I was forced to give life to something much bigger than myself, namely the story of the group. I suspected that the context of my research would open up a discussion about spirituality but was surprised at the results. The discussion about spirituality was an integral part of our research story. Somehow our spirituality didn't occur in a vacuum but influenced our relations with each other. Our contact with each other was and is in principle spiritual in nature. This article would be incomplete without reflecting on the spirituality stories of our group.

\section{DECONSTRUCTING THE PERFECT PASTOR DISCOURSE}

I started this research journey with a bag full of assumptions. I committed myself to the unknown, but I had not shed my bag. During the research process my own assumptions about female pastors were deconstructed. I realised I had set goals for myself as a female pastor and these goals were influenced by the discourse of the 'Perfect Pastor' (my labelling). The Perfect Pastor has the following characteristics:

- She never speaks about problems because it is an admittance of failure

- She copes with all the demands made by her congregation and her family

- She is a spiritual being and does not live with doubt because she has to set an example to the world

- Because not everyone in the church appreciates female pastors, she has to prove herself.

This discourse strengthens feelings of despair, stress and failure. Our conversation with Mary Magdalene assisted us to deconstruct this discourse and made us realise we all share an 'existential fear', a fear of living life to the full. We have created these ideas and we realised none of us is able to achieve these goals. They are just too hard to come by. My co-researchers made me realise that I am not the only one struggling to keep everything together, I am not the only one who doubts and feels alienated from my church's viewpoints.

We felt ready to venture on to the discovery of an alternative story, the story of the group. Mary Magdalene's voice assisted us in moving towards the creation of a new story. My co-researchers agreed that Mary Magdalene's story might be labelled as 'a good, positive' story.

\section{THE SPIRITUALITY STORIES OF THE GROUP}

\section{A unique outcome}

Although suspecting our conversation with one another would touch on spirituality, I never suspected it would become the content of our group story. The story of Mary Magdalene did not focus us on the externalisation of problems, on the bitterness, frustration and disappointment experienced in the church but functioned as a facilitator of a unique outcome (see Morgan 2000:51-58). All the members of our group experienced discrimination in the church in some way and struggled to balance the demands made by the church on the one hand and family life on the other hand. The spirituality stories do not wipe out the problem stories but give directions to face them. In this sense, the spirituality stories overpower the problem stories, thus creating sparkling moments and the possibility of an alternative story for each participant. 


\section{A definition of spirituality}

Miller and Martin (1988:14) describe spirituality as the recognition of a transcendental power or reality greater than us. It is the attempt to conform life to the transcendental. It doesn't necessarily imply being involved in formal religion, but spirituality is always an intentional attempt to unite with God or the divine.

Carlson, Erickson and Seewald-Marquard define spirituality as: ... a profoundly relational and moral way of being, as the primary purpose centres on our intimate relationship with the Divine (which we take the liberty to call God), and how that relationship invites us into communal relations of respect, mutuality, accountability, compassion and love with all humanity, and with all creation.

(Carlson et al. 2002:218-219)

In the case of our support group, our religion or religiosity is an intricate part of our spirituality, namely our belief in God our Creator, Jesus Christ our Saviour and the Holy Spirit, God present.

Anne Carr (1996:201) labels spirituality as a person's spiritual experiences, beliefs and patterns of thought, emotions and behaviour in connection with God. Spirituality is therefore holistic because it not only includes the religious aspect of a person's life but also refers to a person's behaviour, experiences and ethics. Spirituality is therefore reflected in everything one says or does. People, communities, race, culture, gender and history also determine spirituality.

Although we are all aware of the oppressing qualities of spirituality (for example the exclusion of woman in religious ceremonies), the emancipating and healing qualities of our spirituality story are emphasised.

\section{The possibility of an alternative story}

By asking in what way Mary Magdalene speaks with every individual story, our spirituality stories took shape. Our spirituality stories assisted us in counteracting feelings of bitterness, frustration and disappointment experienced in the church, reinforced by the grand narrative we identified as the Perfect Pastor discourse.

Our conversation with Mary Magdalene opened up the possibility of an alternative story for each individual:

- We, as female pastors, have unique voices. We have to learn to concentrate, using them effectively. Our unique voice creates the means for bringing about change in our family lives and in our environment.

- Our spirituality stories are, in fact, our survival stories. By witnessing and experiencing her mother and grandmother's love, co-researcher B experienced God's love. It also gave her the means to voice her unique voice. Co-researcher A experiences God's care in her life - she views her life as a journey facilitated by God's grace and love. Co-researcher C stated that it is God's amazing 'energy' that sets everything in motion. IZ is this same energy that keeps her going and enduring. This energy will also be present in the future, enabling her to endure.

- Our problems and struggles have not vanished. We still have to deal with them. At least we are familiar with one of the grand narratives that feed our fears and problems, namely the discourse of the Perfect Pastor. By sharing our stories with one another, we made an effort to counter the voice of this grand narrative. Its voice doesn't whisper anymore and sneak up on us, thereby ruling our lives. We've learned that it is acceptable to struggle to cope with all the demands presented by work and family. Part of our spirituality stories is to live with doubt and questions. Didn't Mary teach us to integrate paradoxes? Mary didn't need to 'prove' herself - Jesus made her acceptable and gave her the courage to confront the disciples. Maybe it is not necessary for us to prove ourselves all the time because we are acceptable to God. He even strengthened us with a powerful weapon: our unique voices.

Often during the development phase of a research story, the researcher has no idea where she is headed. According to Müller, Van Deventer and Human (2001:1-3) this uncertainty within the boundaries of the narrative approach should not be viewed negatively because it ensures that research develops at its own pace in a certain direction and is not manipulated to confirm a predetermined hypothesis. With time our research changed us in ways that were totally unexpected. I asked the group members whether they wanted to continue to meet and their answer was an unwavering 'yes'. Our spirituality stories, facilitated by Mary Magdalene's story, are still in their infant shoes, waiting to be explored.

\section{REFERENCES}

Albert, S.W., 1996, Writing from life: Telling your soul's story, GP Putnam's Sons, New York.

Atkinson, R., 1995, The gift of stories: Practical and spiritual applications of autobiography, life-stories and personal mythmaking, Bergin and Garvey, Westport.

Bultmann, R., 1971, The Gospel of John: A commentary, Blackwell, Oxford.

Campbell, J., 1982, Creative Mythology, Penguin Books, Middlesex.

Carlson, T.D., Erickson, M.J. \& Seewald-Marquard, A., 2002, ‘The spiritualities of therapists' lives: Using therapists' spiritual beliefs as a resource for relational ethics', Journal of Family Psychotherapy 13(3/4), 215-236.

Carr, A.E., 1996, Transforming grace: Christian traditions and women's experience, Continuum Publishing Company, New York.

Duling, D.C. \& Perrin, N., 1994, The New Testament: Proclamation and parenesis, myth and history, Harcourt Brace \& Company, Orlando.

Epston, D. \& White, M., 1990, Narrative means to therapeutic ends, WW Norton \& Company, London.

Epston, D. \& White, M., 1992, Experience, contradiction, narrative and imagination, Dulwich Centre, Adelaide.

Freedman, J. \& Combs, G., 1996, Narrative therapy: The social construction of preferred realities, WW Norton \& Company, London.

Freedman, J. \& Combs, G., 2002, Narrative therapy with couples... and a whole lot more. A collection of papers, essays and exercises, Dulwich Centre Publications, Adelaide.

Ganzevoort, R.R., 1989, Levensverhalen: Een verkenning in hermeneutisch crisispastoraat, JN Voorhoeve, Den Haag.

Kenyon, G.M. \& Randall, W.L., 1997, Restoring our lives: Personal growth through autobiographical reflection, Praeger, London.

King, K.L., 2003, The Gospel of Mary of Magdala: Jesus and the first woman apostle, Polebridge Press, California.

Meyer, M.W., 1985, 'Making Mary male: The categories 'male' and 'female' in the Gospel of Thomas', New Testament Studies 31, 554-570.

Miller, W.R. \& Martin, N.J.E., 1988, Spirituality and behavioural psychology, Sage, London.

Morgan, A., 2000, What is narrative therapy? An easy-to-read introduction, Dulwich Centre Publications, Adelaide.

Müller, J.C., Van Deventer, W. \& Human, L., 2001, 'Fiction writing as metaphor for research: A narrative approach', Praktiese Teologie in SA 16(2), 1-11.

Pagels, E., 1979, The Gnostic Gospels, Vintage Books, New York.

Price, R.M., 1990, 'Mary Magdalene: Gnostic apostle?' Grail 6(2), $54-76$.

Robinson, J.M., 1990, The Nag Hammadi library in English, HarperCollins, San Francisco.

Rubin, H.J. \& Rubin, I.S., 1995, Qualitative interviewing: The art of hearing data, Sage, London.

White, M., 1998, 'Notes on narrative metaphor and narrative therapy', in C. White \& D. Denborough (eds.), Introducing narrative therapy: A collection of practice-based writings, n.p., Dulwich Centre Publications, Adelaide. 